\title{
Migration patterns and emigrants' transnational activities: comparative findings from two migrant origin areas in Ethiopia
}

\author{
Girmachew Adugna(1)
}

Correspondence:

girmadugna@yahoo.com

Seefar, Better Migration

Management (BMM) Ethiopia,

P.O.Box - 3096 code 1250, Africa

Avenue, Addis Ababa, Ethiopia

\begin{abstract}
Growing literature, including those published in this journal, provide important insights into the complex dynamics of immigrants' transnational engagement by comparing different migrant populations residing in the same host society. However, extant research that provides an in-depth investigation of the interplay and dynamics that exist within the same ethnic origin is either sketchy or non-existent. It is therefore imperative to collect as detail and as relevant empirical data digging deeper into the individual nuances and cultural subtleties that exist within a group of migrant populations originating from a single country. Taking the case of Ethiopian immigrants, this research aims to fill a gap by examining the various overarching different migration regimes that shape immigrants' transnational activities including return visits, non-direct family contacts and several features of remittances, including amounts, roles, directionality and intermediaries. A comparison of the two migration trajectories does not only reflect the dynamics of the configuration of migrant societies within Ethiopia but also the specific labour market demands of different countries/regions in terms of the profile of migrants, mainly their skills (low-skilled, unskilled, high-skilled) and genders (male-labour, female-labour) as well as the social transformations associated with migration and remittances. The legal status of migrants during travel, and upon reaching destination and associated mobility and immobility factors are increasingly affecting the migration outcome of these migrants.
\end{abstract}

Keywords: Comparative migration, Transnational activities, Remittances, Hometown associations, Social networks, Ethiopia, USA, South Africa

\section{Introduction}

Owing to various socio-economic and political factors, over a number of decades Ethiopia is one of the major sending countries in migration. The routes and destinations of these migrations are as diverse as that of the causes of it. This is often dictated by the circumstances present at the time of migration. Over the years, a pattern emerged as to where in the country, why and where Ethiopians migrate. It is important to note that social class, resources, gender, and poverty are key variables along which migration from Ethiopia is being stratified, and there is also important sub-national variation. This has grown more visible since the late-1990s with an influx of both

(c) The Author(s). 2019 Open Access This article is distributed under the terms of the Creative Commons Attribution 4.0 International License (http://creativecommons.org/licenses/by/4.0/), which permits unrestricted use, distribution, and reproduction in any medium, provided you give appropriate credit to the original author(s) and the source, provide a link to the Creative Commons license, and indicate if changes were made. 
skilled and unskilled migrants from Ethiopia migrating to different destinations. Not all Ethiopian migrants have the same experiences, and this has a lot to do with the regional organisation of migration. Different histories locally, and transnationally, generate different outcomes.

There exists a growing volume of literature (Button \& Vega, 2008; Glick Schiller, Basch, \& Blanc, 1992; Lacroix, Levitt, \& Vari-Lavoisier, 2016; Massey et al., 1999; Vertovec, 2004) providing an important insight into the complex dynamics of immigrants' transnational engagement. Most of these studies tend to compare migrant populations who originated from different countries but currently residing in the same host society. However, extant research that provides an in-depth investigation of the interplay and dynamics that exist within the same ethnic origin is either sketchy or non-existent (Torres \& Gioconda Herrera, 2014). There is a tendency to lump all migrant populations into one category and jump to conclusions, resulting in superficial data analysis. It is therefore imperative to collect as detail and as relevant empirical data digging deeper into the individual nuances and cultural subtleties that exist within a group of migrant populations originating from a single country.

Taking the case of Ethiopian immigrants, this research aims to fill a gap by examining the various overarching different migration regimes that shape immigrants' transnational activities including return visits, non-direct family contacts and several features of remittances, including amounts, roles, directionality and intermediaries. In what follows, this paper looks at two migrant origins in Ethiopia, namely Gondar, a northern Ethiopia where it saw early migration to North America, Australia and Europe; and Hadiya and Kembata-Tembaro villages, in Southern Ethiopia, an emergent area of migration to South Africa, largely on an irregular basis.

The migration from Gondar could be characterised as irregular at first but through the years a pattern has emerged due partly to a green card and sponsorship system whereby early migrants, predominantly those who fled the military government's political persecution through the Sudan, began to take their families who left behind. It could also partly due to those who remain locally were motivated by those who left. One could not for instance find a similar pattern from other parts of Ethiopia, say Gojjam, North West Ethiopia, indicating thus the causes and process of migration in Ethiopia varies due to various driving forces. This is also true for the variation in characteristics of the contexts of reception. This suggests the importance of time and temporalities in discussing migration dichotomies and patterns in general and a migrant's life course in particular. Time is what allows us to see change or transition from being an undocumented immigrant to having a legal residence. This approach highlights the "temporalization of presence," (Coutin, 2000), whereby the qualification of individuals for different legal dispensations is based on the paperwork they can produce to document their presence (Menjivar, 2011, p. 379).

Empirical data shows that migration from Gondar and Hadiya and Kembata regions are driven due to various causes, indicating the fact that there exists no single theory to account for migration from a given country, given that most exhibit some level of distinct regional histories. The different processes have been at work in the histories of migration from these two regions to these two specific destinations; the US and Israel, vs. to South Africa. As this study reveals, in the Ethiopian context, there is important sub-national variation. The paper places this in a historical perspective and shows how 
and why migration in these two areas has become so prominent taking into account the social dynamics of the context of departure.

This paper also shows how those who are poor as well as those who are economically better-off migrate. It demonstrates the cause of migration is not always money, even though economic migration accounts to a significant majority. However, apart from being poor, there are other factors that need closer consideration. Unfortunately, the research on migration gives no particular attention to these factors. As a result, there lacks a comparative empirical data on the intra-national differences that shape migration flows and many of the characteristics and changes of these differences are still unknown. This is also the case in the broader migration literature (Goldring \& Landolt, 2014; Rivera-Sánchez \& Lozano-Ascencio, 2014).

Although the field of migration studies vastly expanded in the last decade, there has been a broader 'receiving country bias' which obscures not only the role of origin states (Vezzoli, 2014) but also intra-national variations within sending countries. There is also a tendency to put all migrant "groups" or populations mainly from developing countries into a single box (Goldring \& Landolt, 2014), which was considered to be a valid "container" or basis for generating identities, practices and organizations (Rivera-Sánchez \& Lozano-Ascencio, 2014, p. 13). Arguably, the role of contexts of departure in influencing the processes of migration flows and variation in the types, scope and dynamics of transnational engagements has been little studied. Theoretically, this paper argues for the utility of taking sub-national variation in migrant origin countries by interrogating intra-national differences in migration flows. This enables us not only to avoid a broader receiving country biases in migration research but also to avoid methodological nationalism.

In comparative migration research, typical research designs build on the comparison of two or more groups in a given destination or one or more groups in more than one place of settlement and expand this to include their transnational social fields (Goldring \& Landolt, 2012, p. 104). Interrogating migration flows from within a sending country is crucial. Contexts of departure and reception are operationalised as geographic locations (Goldring \& Landolt, 2012). The former usually fall in one analytical category with a preconceived assumption that the composition and characteristics of migrants and the drivers of their movement are similar. That means there is a tendency to ignore sub-national variation in shaping international migration flows. Simply, such approaches of methodological nationalism risk missing the complexities of the phenomenon and the trajectories of different forms of migration from a single origin country.

In contrast to what is very often suggested in the migration literature, the results of this study show that poor families do "send" migrants, but to places that require lower investment. Future remittances serve as collateral for a loan especially for the poor, and it is used to finance migration. This finding directly implies that the financing of migration should be considered as an important variable in theorising people's mobility. Well-to-do families mainly from urban Ethiopia tend to hold a relative advantage and capability over desperate labour migrants in choosing their destinations, and financing migration from their own sources. This finding also implies that migration should not always be explained through relative deprivation as NELM states. Instead, it is also a process that occurs as a result of wealth (to a certain extent) and, most importantly, to move out of absolute deprivation. 
This study confirms that migrants, as NELM proposes, are not just motivated by earning more at the destination, but also because their remittances diversify the sources of income available to their families left at home and provide insurance against the risk of origin-based income source failures. However, it also demonstrates that, in many cases, the decision-making process goes beyond the household migration decision model that is proposed by NELM. This is because Ethiopian migrants realise their aspirations to migrate through negotiating their decisions with a number of people and local institutions, which enables them to overcome financial and non-financial resource constraints during and after migration.

This article attempts two kinds of analytical work. First, its comparative perspective helps to understand the different migration systems that have arisen within one country, and explaining them in a way that takes into account several dimensions and variables. Such a comparative approach also helps to identify the social, institutional and labor regime particularities of each sending region in Ethiopia. In this case, comparative analysis "offers the advantage of minimizing methodological nationalism" (Ariza, 2014, p. 43). Second, it attempts to understand how emigration patterns affect the ways in which immigrants operate within transnational spaces. In doing so, the paper seeks to make a contribution to the transnational migration literature by interrogating intra-national differences in migration flows and the relationship between migration patterns and remittance flows as well as the different roles that remittances play in mature and emerging emigrant communities, both in urban and rural contexts, along with the ways in which migrants and their networks substitute the function of financial institutions engaged in the remittance industry. Important empirical contributions to migration studies.

Having outlined the overall gist and introduction to this paper in "Introduction" section, the remainder of this study is organised into six parts. "Transnational perspective of migration: a review of literature" section provides the review of related literature on migrant transnationalism and how legal status at destination influence immigrants' transnational activities. "International migration in Ethiopia" section highlights recent trends and patterns of international migration in Ethiopia; followed by "The South Ethiopia - South Africa and Gondar - USA migration corridor" section which compares the drivers and patterns of international migration from these two distinct regions of Ethiopia. "Transnational communication and family visits" section examines remittance flows and its utilisation patterns, along with the negative and positive impacts in both areas. And finally, "Conclusion" section, compares the two cases and analyses their implication for the transnational migration literature.

\section{Transnational perspective of migration: a review of literature}

Recent scholarship has emphasised migrants' transnational engagement and its effect on communities of origin, and the role of social networks and policy initiatives in mobilising these resources (Button \& Vega, 2008; Glick Schiller et al., 1992; Vertovec, 2004). In a highly interconnected world, the trends and patterns of migration are dynamic and include a multifaceted interaction of traditions and customs across place and time. This scenario is explained by "the emergence of transnational communities" (Castles, 2007, p. 353). The term transnationalism, not used in connection with families before 1990, is usually associated with the movement of goods and commodities across 
national borders (Bryceson \& Vuorela, 2002). Arguably, the issue of transnationalism is not a new phenomenon, as international migration has long involved cross-border practices. However, there has been a dramatic change in technology as well as social, economic and political arenas that have magnified the concept of transnationalism (Portes, 2003). The advent of modern communication technologies has revolutionised migrants' ability to communicate with their origin areas (Vertovec, 2004). Importantly, they allow linkages to be maintained and strengthened by more frequent as well as increasing opportunities available to people for creating various types of co-presence (Baldassar, 2008, p. 263). Solid transnational family ties can be sustained for many years and pass over generations (De Haas, 2011). Over time, these relationships are "revitalised, strengthened and reaffirmed through virtual, proxy, physical and imagined co-presence" (Baldassar, 2008, p. 263).

Studying transnational activities of migrants has served to emphasise the multiplicity of identities and roles that shape the daily experiences of immigrants and their descendants (Morales \& Jorba, 2010, p. 268). The transnational networks of migrants are economically linked to the development of migrant source areas through investment, remittances, and creating a market for local producers and service providers (De Haas, 2011; Hugo, 2012; Orozco, 2005). Also, these networks are characterised by complex cultural, social, and political relations (Faist, 2010). Social networks that "carry obligations, reciprocity, and solidarity between migrants and communities of origin" (Faist, 2010, p. 192) ensure continuity of resources flows, and facilitate migrants' transnational engagement, including skill and knowledge transfer (Levitt, 1998).

Increasingly, people living in a country other than their own, develop and sustain connections with origin families and communities (Glick Schiller et al., 1992). However, the latter, although often assumed as passive recipients of remittances, are in fact important agents who actively engage in maintaining and building these networks. Hence, the non-migrant population (also called "non-migrant" or "local" transnationals) must be acknowledged as active players in transnational communities (Orozco, 2005). The survey findings presented in this paper show that families left-behind are active agents not just because they send reverse remittances (mainly in the form of goods) to migrants and undertake occasional visits, but also because they play a role in resolving conflicts that can occur among immigrants and transnational families (see, e.g., Zewdu, 2017a for detail). Although immigrants' transnational activities can take many forms, including social, cultural, religious, economic, and political (Baldassar, 2008), this study focuses on the social (family visits and transnational communication) and economic (family and collective remittances). Importantly, it discusses how migration patterns and legal status at destination affect the transnational activities of immigrants and their families left behind.

Legal status at destination and immigrants' transnational engagement

Arguably, the empirical literature on illegality effects is still small, especially on remitting behavior (Schluter \& Wahba, 2009). The extent of undocumented migration and the resulting financial flows point to the need for focusing on the different ways in which illegality affects transnational practices and linkages. This is also of particular interest as undocumented migrations are primarily labor migrations (De Genova, 2002) which in the first place is driven by remittances. Informal remittances are often related 
to undocumented migration and such kind of studies are important for policymakers and need to be further explored. A recent study by Isaacs (2017) suggests as much as $78 \%$ of the money sent home by the Ethiopian diaspora may be going through informal channels in some corridors. This is more pronounced in the South Africa-Ethiopia and Middle East-Ethiopia remittance corridors, where migration is increasingly characterised by its irregularity.

Many studies show that legal status affects the ways in which migrants operate within transnational spaces (Cvajner \& Sciortino, 2010; Düvell \& Jordan, 2002; Koser, 2010; Waters \& Gerstein Pineau, 2016). The social space of "illegality" is an erasure of legal personhood, - a space of forced invisibility, exclusion, subjugation, and repression that "materialises around [the undocumented] wherever they go" (Coutin, 2000, p. 30; De Genova, 2002). Some scholars showed how having or lacking legal status affects immigrants' integration, thereby, their transnational engagement, not just the economic dimensions, but also the socio-cultural and political (Castañeda, Morales, \& Ochoa, 2014; Lacroix et al., 2016).

Legal status affects immigrants' paths to integration in a variety of ways, across a wide range of activities, and with varying degrees of intensity (Waters \& Gerstein Pineau, 2016, p. 93). It has become increasingly important to immigrant integration. In their studies of Latin American immigrants in the US, Itzigsohn and Giorguli-Saucedo (2002) reported that immigrants who are least or most integrated into the destination society are more likely to have high levels of transnational engagement. The least integrated ones tend to involve in 'reactive transnationalism' mainly to compensate their social exclusion at destination and others, due to their integration and economic success in the host society, what Itzigsohn and Giorguli-Saucedo (2002) refers "resource-based transnationalism." However, this is not something that holds in all contexts and at all times. The literature indicates that integration and transnationalism can be interconnected to each other in many ways; it could be positive, negative and may have a non-causal relationship (Malini, 2014). Some noted that a high degree of integration is associated with low degrees of transnationalism and vice-versa, which is a negative relationship. Some immigrants, especially those who are marginalised, could be neither transnational nor well integrated. As Itzigsohn and Giorguli-Saucedo (2002, p. 784) noted, immigrants with longer time in the United States are more likely to participate in transnational activities, suggesting that the 'process of incorporation and the creation of sociocultural linkages are intertwined in complex ways.'

Migrant "illegality" has risen to unprecedented prominence as a "problem" in policy debates and as an object of border policing strategies for states around the world (De Genova 2002, p. 419). Undocumented migrants are vulnerable because they face a gap in state protection. Their labor has been criminalised as "illegal" and subjected to excessive and extraordinary forms of policing (De Genova, 2002, p. 439). They also live in fear of deportation and exposed to the risk of exploitation and estrangement of family and community contacts as a result (Ramji-Nogales, 2015).

As noted above, legal status affects the various aspects of immigrants' lives that range from employment and income to access to higher education, social services and healthcare (Waters \& Gerstein Pineau, 2016). Despite the many legal challenges, undocumented migrants, like that of documented counterparts, are still enabled to develop and sustain connections with origin families and communities (Baldwin-Edwards, 2008; 
Donato \& Armenta, 2011). They also "invariably engaged in social relations with "legal" migrants as well as citizens, and they commonly live in quite intimate proximity to various categories of "documented" persons - sometimes as spouses, frequently as parents or extended family members (often sharing the same households), as well as neighbours, coworkers, and so on" (De Genova, 2002, p. 423). Such proximity and social interactions support undocumented migrants through life's daily challenges.

It is important to note that people often transition between different immigration statuses.

The same legal status in the destination can also mean different things in different settings. For example, being undocumented in the US in the 1980s was quite different from being so now. There was more mobility, less deportation. Most immigrants of the past did not face the complexities that the contemporary immigration system poses and presence in the country was generally enough to guarantee access to public benefits (Waters \& Gerstein Pineau, 2016). However, the situation in South Africa remained static. Ethiopian migrants remain undocumented despite their long illegal presence in South Africa. This indicates that it is not just the status of irregularity or being undocumented, it is also about the policies surrounding that. Policies not only about access to services and jobs, and ongoing presence but also about enforcement, criminalisation, etc. These policy changes have contributed to the proliferation of legal statuses, with important consequences for immigrant integration (Waters \& Gerstein Pineau, 2016, p. 93). De Genova (2002) also contends that "Illegality" is the product of immigration laws.

Undocumented migrants are very unlikely to get involved in the politics of the host society (Cvajner \& Sciortino, 2010). Indeed, their inability to freely move across national borders and within the host country is one of the most visible and well-recognised effects of undocumented migration. Irregularity also affects their investment, knowledge, and skills transfer schemes (Castles, De Haas, \& Miller, 2014; Koser, 2010). It also reduces immigrants "propensity to engage in non-mobile transnational activities" including remittances and family contacts (Vickstrom \& Beauchemin, 2016, p. 7). Conversely, some argue that undocumented migrants tend to maintain more frequent indirect transnational relationships (communication and remittances), as they do not have the opportunity to visit their families left behind (Hosnedlová \& Stanek, 2014).

This study suggests that irregularity doesn't prevent immigrants from sending remittances and maintaining transnational connections, although it greatly alters the way they communicate, remit, and exchange resources across borders. All these constraints, indeed, would be overcome when refugees and other undocumented immigrants secure legal status, or when they receive host-country passports (Koser, 2010). Clearly, immigrants are different in many subtle ways, including their personal characteristics, migration experiences, level of integration, legal status at a destination, as well as the opportunities and contexts of their homelands and current places of residence. This paper engages these issues to examine sub-national variation in migration streams and transnational spaces. In so doing, it attempts to contribute to the literature on transnational migration, remittances and illegality/legality status.

\section{International migration in Ethiopia}

In the past few decades, Ethiopia has become a very important sending country in migration, and the destinations and the ways of migration are indeed very diverse. 
Large-scale emigration began in the mid-1970s when the monarchy was overthrown by a military dictatorship. Before the 1974 revolution, some people left for Western countries in pursuit of education and the rate of return was reportedly high (Lyons, 2009; Terrazas, 2007). However, international migration has subsequently increased, especially in the last two decades and has become more complex.

Currently, emigration is occurring at unprecedented levels in Ethiopia, in three major migration corridors: Eastward to the Gulf States and the Middle East, southward to South Africa and Northward - trans-Saharan migration to Libya and beyond. The "feminisation of migration", the emergence of Ethiopian villages as an important source of low skilled labour for the international labour market and the intensification of skilled migration, define the country's recent migration terrain (Zewdu, 2017a). Recent government data puts the estimate of Ethiopian diaspora at over three million, mainly concentrated in the US, Middle East, and Europe.

In Ethiopia, the landscape of migration has changed from that born-out of-conflict to undocumented migration, mainly driven by economic reasons. Migrating through regular channels is increasingly challenging and beyond the reach of the poor, so, migrants opt to use the other option: irregular movement. Undocumented migration - also known in other names - irregular, unauthorised, clandestine, or illegal - involves crossing national borders "without proper authority or violating conditions for entering another country" (Düvell \& Jordan, 2002, p. 15). These categories are "posited always from the standpoint of the migrant-receiving nation-state, regarding outsiders coming in, presumably to stay" (De Genova, 2002, p. 421).

There are interesting conceptual discussions about the language used to refer to policies that illegalise people (see, De Genova, 2002, for details). Generally speaking, migrants could be identified as irregular at two stages. One, through the ways in which they cross internationally recognised borders (i.e. without authorisation) and two, the ways in which they work and stay in a destination country (i.e. violating immigration laws). This points to the importance of distinguishing between irregularity in travel, and legal status on arrival. During travel, it matters regarding cost, debt, duration of travel, risks of migration, etc. At the place of destination, "illegal" status affects the way and patterns of remittance flows. However, the dichotomy between - regular and irregular or legal and illegal migration - is often criticised by many scholars, as the status of immigrants can change from one category to the other too easily and quickly (Castles et al., 2014).

The distinction between regular and irregular moves is blurred, as migrants use both channels in the course of migration. Some legally registered agents are also involved in undocumented migration, as this study reveals. A recent assessment of undocumented migration from the Horn of Africa to South Africa shows that Ethiopia and Somali, but also Kenya, are the major source countries, with two-thirds of the estimated flows of smuggled migrants originating from Ethiopia (Horwood, 2009). The departure of skilled migrants to Western countries and other emerging economies in Africa is also on the rise. While studies on female labour migration to Arab countries shed some light on the plights of domestic workers and their vulnerability to various forms of abuse and exploitation, the patterns and determinants of southward migration to South Africa are little understood and will be addressed in comparison with Gondar, one of the most notable migrant-sending areas, since the late 1970s in this paper. This is the first paper 
attempting to make a comparative analysis, using migration and remittance data from different migrant-sending areas in Ethiopia.

\section{The study setting}

Although Ethiopia has seen a reduction in refugee flows over the past decade, documented and undocumented labour migration has significantly increased. As elsewhere, migration from Ethiopia is defined by a temporal and a spatial dimension. This paper, as indicated above, compares two migration-remittance systems in contrasting regions of Ethiopia. One - Hadiya and Kembata region in Southern Ethiopia, which are known for sending young and low-skilled migrants, predominantly to South Africa over the last decade. Nearly $95 \%$ of these migrants are undocumented (Kanko, Bailey, \& Teller, 2013). The second is Gondar, which has been an important source of emigrants since the late 1970s, when the country's first large wave of emigration occurred. The USA and Israel have been the main destinations for migrants originating from this province. As the largest proportions of refugees from Gondar were resettled in the United States, it has been maintained as a popular destination over time, with two-thirds of respondents having one or more family members residing there. In Gondar, migration was caused by political instability in the late 1970s; in Hadiya and Kembata communities, migration is driven mainly by economic reasons. It is important to note that conceptualising households as the unit of analysis is challenging and must take into account how households are structured in cultural, spatial, and temporal dimensions, and where the complicated layers of power dynamics are embedded, including gender and intergenerational relations (Evans, 1991; Guyer, 1981). It implies that the household, though important as the unit of analysis, must be viewed alongside mesolevel and macro level factors, as well as through a transnational lens.

Figure 1 shows the study areas: Gondar, a city in northwest Ethiopia, and Hadiya and Kembata-Tembaro zones, that are located in northern part of Southern Nation, Nationalities and Peoples' Regional State (SNNPR), are situated in different socio-cultural settings. Gondar, founded in 1635 by Emperor Fasiledes, is one of the ancient cities that has served as the capital of the country for over 200 years (Getahun, 2007). As a historic city, with imperial palaces along with numerous cathedrals, Gondar is one of the most important tourist destinations in Ethiopia. Moreover, the city, located at the junction of Metema and Humera, the country's major cash crop producing areas, the Tigray Regional State, and along the border of Sudan, is a central hub of trade.

Kembata-Tembaro ${ }^{1}$ and Hadiya Zones $^{2}$ are two of the 14 administrative zones and 4 special Woredas (districts) in SNNPR - one of the most populous and ethnically diverse regions. A total of 2.4 million people live in both zones, with the largest in Hadiya $(1,563,441)$ followed by Kembata-Tembaro zone $(841,663)$. The Hadiya and Kembata-Tembaro Zones, with a population density of 342 and 502 person per $\mathrm{km}^{2}$ (Federal Democratic Republic of Ethiopia Population Census Commission, 2008), are the most densely populated areas in the country. Notably, scarcity of farmland remains a daunting challenge for the region with an average of 0.6 ha of land per household (Federal Democratic Republic of Ethiopia Population Census Commission, 2008). The proportion of cultivated land is high in Kembata 


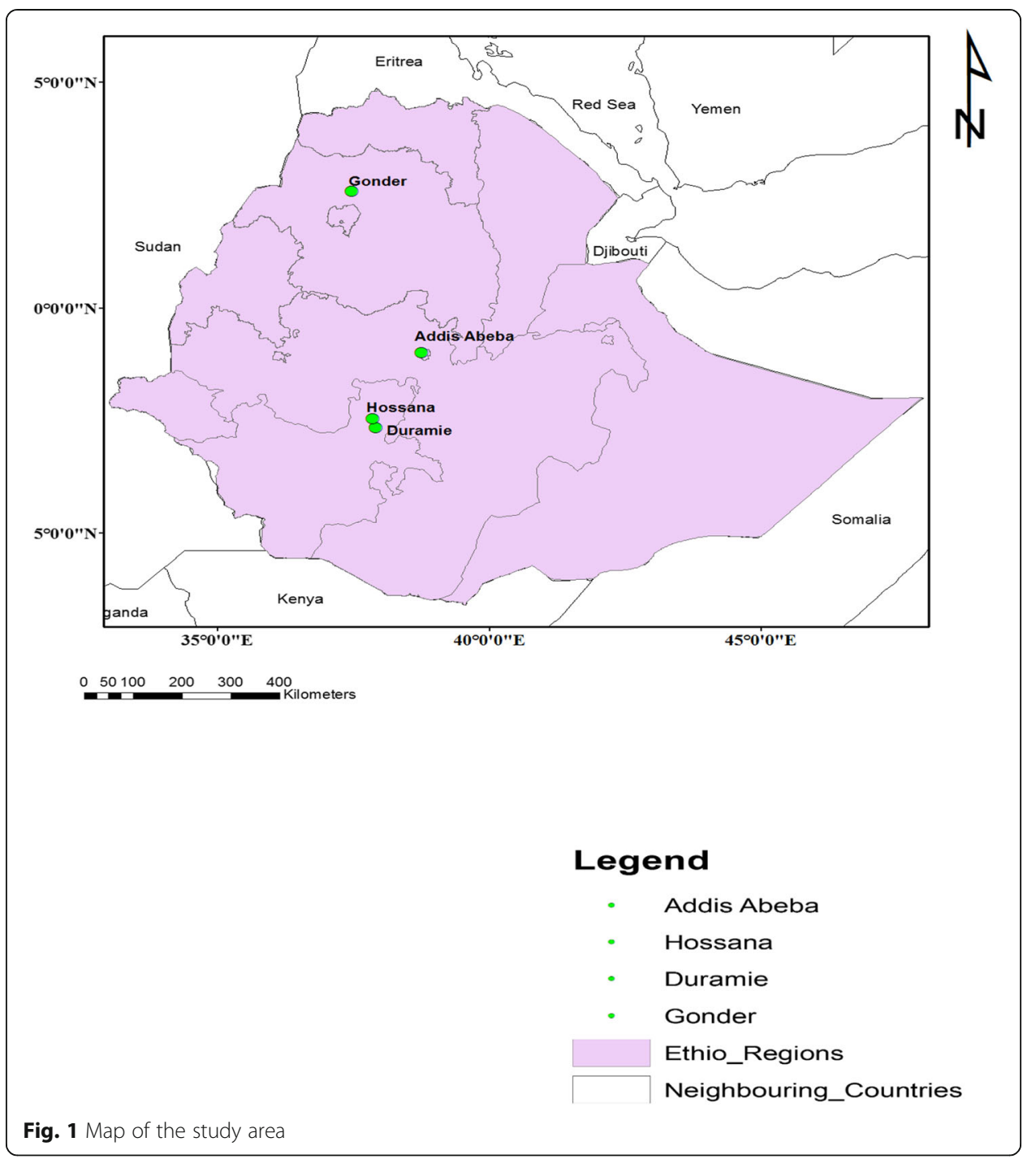

zone $(75.2 \%)$ compared to Hadiya (57\%). Gondar is also the most populous city in the Amhara Region and fifth largest nationally. Its population had grown from 112,249 in 1994 to 206,987 in 2007.

\section{Methods and approaches}

The research was conducted in two different sites (Gondar, Hadiya and Kembata-Tembaro zones) to examine how and why migration in these areas has become so prominent and to understand how these different migration-remittance systems shape several features of remittances, including amounts, roles, directionality and intermediaries. It also helps to document different types and modalities of international migration and show some relations and variations in the dynamics and process of migration including, the routes taken and associated risks by low skilled labour migrants to South Africa and those moving to western countries, mainly to the US. Comparative studies have examined different migrant populations in one setting of destination (Goldring \& Landolt, 2014), suggesting more work to be done to compare migrations from two or more settings in origin. 
Comparative research offers the promise of enriching transnational migration studies (Goldring \& Landolt, 2014). In this study, it was important to adopt a comparative analysis, due to the complex dynamics of migration systems, including the emergence of new forms of geographic and migratory mobility, together with increasing number and composition of migrants from different regions of Ethiopia. As Ariza (2014, p. 51) indicates, three advantages from the use of the comparative method in the study of migration processes: (a) minimising the risk of tautological statements; (b) reducing the tension between the micro and macro levels of analysis; (c) combating methodological nationalism by contributing to a transnational understanding of the current migration process and of the social transformation associated with it.

In this comparative exercise, the context of migrant origin areas is analysed both from a "local geographic and social space" perspective and the "social organisation of migration category" (Rivera-Sánchez \& Lozano-Ascencio, 2014, p. 14). A comparison of the two migration trajectories does not only reflect the dynamics of the configuration of migrant societies within Ethiopia but also the specific labour market demands of different countries/regions in terms of the profile of migrants, mainly their skills (low-skilled, unskilled, high-skilled) and genders (male-labour, female-labour) as well as the social transformations associated with migration and remittances. It also helps to understand whether these variables are being reconfigured through migration. Furthermore, adopting a comparative analysis in migration studies allows for "the relativisation of statements, and at the same time, the distinguishing of the specific from the general, effectively responding to individual factors in relation to the characteristics of the group or the socioeconomic structure of the receiving country" (Ariza, 2014, p. 51). The same author underscores that in epistemological terms, comparison leads to a process of classification that discriminates between similar and different (Ariza, 2014, p. 51). It implies that a careful, logical and systematic categorisation of phenomenon satisfies the central role of the knowledge process.

Often, migrants from a given country such as Ethiopia, are homogenised as a single group, based on the assumption that the drivers, processes, and characteristics of migratory flows are the same. That means, we only consider one context of departure, instead of many. It is, therefore, important to understand the diverse context in societies of origin and unpack them. If we are taking national origin as a central unit of analysis, we risk overlooking important sub-national variations and the profiles of migrants (social capital) in shaping the migration trajectory. Torres and Gioconda Herrera (2014) also suggest the importance of carrying out 'dense' studies in the place of origin; otherwise, the social dynamics and the transformations that occurred there would remain invisible.

With the aim of sufficiently comparing similarities and differences between these two regions in Ethiopia, the comparative analysis involves a number of variables, including: the different types of locations of origin (urban-rural), legal status situations during migration and in destination, histories and recency of migration, as well as different contexts of reception in two countries, namely South Africa and USA. As Rivera-Sánchez and Lozano-Ascencio (2014, p. 6) argue, the complexity of social reality demands integral or integrated explanations and not only partial perspectives on empirical phenomena. However, in this comparative exercise, the emphasis will be placed on how the migration systems evolve in these two areas and the effect from the experience of 
migrating to these two specific destinations, as well as how these shape the transnational practice of migrants and their families left behind.

A mixed methods approach was adopted, involving the collection of both quantitative and qualitative information. This approach was extremely important in this study, given the fact that migration and remittances are a complex issue that requires obtaining the perspectives of different stakeholders. This approach helped to obtain "high degrees of both representativity and depth in the study of migration as a social process" (Massey, Alarcon, Durand, \& Gonzdilez, 1987, p. 12). Data used in this study were derived from a cross-sectional household survey conducted in Gondar, Ethiopia, between March and October 2013 among 544 migrant households with one or more members who had emigrated abroad. Of 544 interviewed migrant sending-households, the majority (58.8\%) were male-headed, while the remaining $41.2 \%$ were female-headed, with many widowed. The survey also had collected economic and socio-demographic data about family members living abroad $(n=845)$ as it greatly affects the trend and pattern of remittance-flow and the way they communicate.

The survey was designed to examine the dynamics of transnational family relations, the communication media employed, and the implications for resource transfers across national borders. The questionnaire collected data about the demographic details of migrant families, (including diaspora members), their experiences on migration, remittances, and transnational family linkages. As this paper analyses data collected from origin areas, it was not possible to get the perspectives of diaspora members. Nonetheless, there is value in collecting the socio-economic and demographic data of families left behind and their diaspora members, and in this case, these data shed light on the types of communication adopted, whom they preferred to communicate with and how often. The samples were drawn from residential areas, private colleges, banks, other public places, such as recreation centres and Internet cafes. It was also further substantiated by interviews and focus group discussions with migrant families and returnees. The Kebeles (the lowest administration unit) in Gondar with a high proportion of migrant families were mapped in collaboration with relevant government officials, elders, and community-based organisations, who have an understanding of the city's demographic and historical development. Kebeles (6 out of a total 12) with the highest concentration of migrant neighbourhoods were chosen, and the number of sampled households was proportional to the size of residential blocks and respective population size. Snowballing methods were used to identify potential participants. An effort was made to draw heterogeneous samples with respect to gender, income, and absent members' country of residence. Although by no means representative, the study was able to draw a sample that intensive field investigation indicated was representative of migrant-sending households.

In addition, the paper draws on semi-structured interviews and focus groups with a total of 58 migrant families, returnees, community elders, local government officials from Hadiya and Kembata region. In-depth interviews were undertaken with 15 migrant family-heads or other members ${ }^{3}$ in Hadiya and Kembata villages who had a good knowledge of the household economy and pattern of remittance usage. A further interview was conducted with 10 returnees who had been living in South Africa for many years and potential future migrants. These interviews explored in detail the motivations behind and their experiences of migration and how technologies change the way they 
communicate with families across borders. Key informant interviews were also undertaken with more than 33 carefully selected individuals and Government organisations, whose formal or informal engagement with the community gave them knowledge of the subject in question. Banks, migrant recruiters, and illegal foreign exchange providers (black marketeers) were also interviewed. In addition, three focus group discussions were conducted with migrant families, returnees, teachers, and community elders.

In addition, 19 in-depth interviews were carried out with 10 migrant families, four (male) migrants who had travelled home to visit family, and five returnees (3 male and two female) who had been living in the United States and Israel. These interviews explored in detail the motivations behind and their experiences of migration and how technologies change the way they communicate with families across borders. Key informant interviews were also undertaken with more than 20 carefully selected individuals and organisations in Gondar, whose formal and informal engagement with the community gave them knowledge of the subject in question. These interviews were helpful to understand migrant transnationalism and whether this brought social change in the community and whether its effects change over time and space. With 25 people, three focus groups were also conducted in Gondar with migrant families, non-migrant households, community elders, teachers, remittance-recipients, and non-recipient youth. The focus groups were used to explore migrant families shared and distinct experiences of separation and family relationships, at a distance.

\section{The South Ethiopia - South Africa and Gondar - USA migration corridor}

In Gondar, cross-border migration was initiated by political insecurity in the late 1970s, but has intensified over time through the interplay of a combination of different factors. The severity of the qey shibir (Red terror) campaign in Gondar and its geographical proximity to the Ethio-Sudanese border paved the way for many to flee Ethiopia. As the largest proportions of refugees from Gondar were resettled in the US, it has been maintained as a popular destination over time, with two-thirds of respondents having one or more family members residing there. On the other hand, young men from the villages of Hadiya and Kembata regions migrate southward to South Africa for economic needs. As indicated above, South Africa is an emerging migrant destination for East African migrants, including those from Ethiopia. An estimated $95 \%$ of the Horn of African migrants arrive in South Africa on an irregular basis (Horwood, 2009). While the migration of Ethiopians to the Republic of South Africa began in the mid-1990s, the flow has become more significant over the past few years (ibid). Recent Government estimate indicates that about 120,000 Ethiopians work and live in South Africa, and the flow has dramatically increased as a result of the effective operation of migrant smuggling networks. However, since the majority are irregular migrants, they are invisible, and nobody knows the true figures. Only a few people originating from households who receive remittances and/or who have better resources, notably farm and cattle, emigrate through regular channels. This also includes women who migrate to join new husbands in South Africa, which are often arranged through transnational migrant networks.

Once started by political instability in the late 1970s, cross-border mobility has been increasingly driven by chain migration, the DV programme, a quest for a better life, from relative deprivation, in pursuit of home, and for education. The reasons for migration, 
however, greatly vary across gender and generations of emigrants. Indeed, migration is not always driven by economic factors. In Gondar where social status is increasingly defined through migration, many well-to-do families send members abroad not only as a source of remittances but as a source of pride. However, the departure of these 'social migrants' can also be a strategy to diversify risk over the longer term. This suggests that migration is a social process on the one hand, and wealth is both a cause and consequence of migration on the other. In Gondar, the 'culture of migration' has developed over the years and, many have migrated to America. The majority of emigrants, who fled to Sudan in the late 1970s, were resettled in America. Once refugees resettled there, their immediate and extended families have continued to join them from the mid-1980s onwards. The survey shows that about $40 \%$ of respondents had members who had joined earlier migrants abroad. Marriage-related migration takes the leading share among network migrants. Nearly one-tenth of households interviewed had a member who moved abroad for marriage with a diaspora. Marriage tends to be a post-migration phenomenon, which is often arranged through transnational social networks.

Marriage is one of the areas where local inhabitants get an opportunity to migrate abroad. Migrant-sending families in Ethiopia plays an important role in connecting recent departees with long-term emigrants. In other words, they serve as an entry point to begin accessing the supporting transnational migrant networks (Zewdu, 2017a). Migration or aspirations to emigrate tend to delay marriage, especially among females migrating to Arab countries as domestic workers. However, in Gondar many females moved abroad, especially to the US through establishing marriages with the diaspora. In terms of outflows, the gender imbalance is not as pronounced as females account for about half of the total outflow. However, in other Ethiopian migration corridors, the pattern of migration is highly 'gendered' where young, male villagers, with little or no education, migrate southward to South Africa, and young women from the villages and small towns of Wollo and Oromiya region tend to disproportionately migrate eastwards to the Gulf and Arab countries.

In Gondar, although the gender disparity is less pronounced in terms of outflow, the migration pattern is highly gendered, in terms of the drivers and consequences of movement. For example, males dominate in cross-border mobility caused by conflict and others emigrate in search of education. They account for over two-thirds of political migrants. On the other hand, women are more likely than men to migrate through the $\mathrm{DV}^{4}$ programme (57.4\%) and family reunification (59.5\%). Marriage-related migration takes the leading share among network migrants. The migration of women to Arab countries tends to be undertaken independently, whereas their migration to Western countries is often associated with marriage and other forms of family migration. This corroborates the findings of other studies. For example, Piper (2006) argues that women dominate migration to the developed world through family reunification.

Once initiated by qey shibir, migration became self-sustaining and an integral feature of life in the study area. It is impossible to understand the intensified levels of emigration from Gondar without understanding the role of migrant networks. Similarly, (Getahun 2007, p. 122) argued that:

the migration of Gondere's to America that begun through refugee resettlement, had now transformed itself into chain migration, family reunion, and hence the preponderance of Gonderes in America and elsewhere. 
The DV program is also important, as nearly a fifth of households had members who were able to enter America through this program. An estimated 50,635 Ethiopians have entered the US through the DV programme between 2003 and 2015 annually. This does not include DV lottery winners, whose Visa applications were rejected for several reasons, including failure to pass medical examinations and presenting false documents.

The cumulative effects of these flows have resulted in the growing concentration of migrants originating from Gondar in America and they have become the largest group of Ethiopian migrants residing there (Getahun, 2007). Migrant networks, which have been in the making for over three decades, have also shaped the post-arrival settlement pattern. This is more pronounced among family and DV emigrants. Lyons (2009) reported that cities like Los Angles, California, and Seattle in Washington, are widely inhabited by emigrants originated from Gondar, whereas ethnic Oromos dominated Minneapolis, and Columbus-Ohio.

Network migration is even more important in the South Ethiopia - South Africa undocumented labor migration corridor. While Ethiopia is a multi-ethnic country, with over 80 ethnic groups, two particular ethnic groups, notably, Hadiya and Kembata communities, predominantly migrate to South Africa. In this region, it is hardly possible to locate a village that does not experience out-migration. However, certain villages and districts, namely Soro, Limo, Misha, Gombora in Hadya Zone, and Domboya, Angacha, and the Doyo Gena districts in Kambata Zone, are typical emigrant localities. Interviews conducted with various individuals and institutions in Hosanna show that this movement was started in 2000, when an Ethiopian diplomat, who had been working in South Africa, helped a group of individuals (i.e., his relatives) to emigrate to South Africa. The idea of chain migration being started by a single event in 2000 has expanded and continued over a massive scale in the past decade. Currently, migrants originating from this region make up the largest Ethiopian community in South Africa (Horwood, 2009; Kanko et al., 2013). Although emigration started over recent years, the scale and level of outflow are very high in these villages. The case studies suggest that once migration is added to a community's social capital it is more likely than other forms of capital to induce migration (Haug, 2008). Network migration is a key driver of spatial mobility, especially in Africa (Lucas, 2008).

This study showed that chain migration is not only confined to the realm of migrant families but has multiplied across the community to encompass non-migrant households as well. Migrants with better network connections and resources are likely to secure loans and to shorten the length of migration by starting work in destination regions shortly after arrival. This indicates that migrant local and transnational social networks play an important role in triggering or structuring migration. Migration tends to be a household strategy. Parents, on some occasions, also encourage youthful household members to leave for South Africa and send remittances home - as a strategy to widen income sources and to build on household livelihoods. The primary motive behind migration is to move out of poverty or to improve the living standards of their family through remittances. The perceived better opportunities in South Africa are significant (Kanko et al., 2013). The socio-economic changes observed for migrant origin households and the circulation of migrant success stories in the villages are also prominent incentives for emigration. The impact of migration tends to be more visible in the context of villages. As a result, success stories are circulated rapidly across them 
and inspire many more to migrate. It is also important to note that social networks work and continue to expand because there is ongoing demand for undocumented (vulnerable, exploitable) workers in South Africa.

Undocumented migration to South Africa requires crossing several African countries, entails high risk, including physical and emotional stress, being imprisoned, deportation and death (see e.g., Horwood, 2009 for details). Similarly, De Genova (2002, p. 437) noted that the "illegality" effect of protracted and enduring vulnerability has to be recreated more often than on the occasions of crossing the border. Despite its irregularity, the migration process is voluntary and self-initiated as the micro-level neoclassical theory underscores. Of particular note, migrants are taking calculated risks, weighing the material and non-material benefits that migration could bring to the entire household, compared to staying with unmet aspirations. On the other hand, the pattern of migration from Gondar tends to be regular, compared to other Ethiopian migration corridors. The survey shows that $90 \%$ of emigrants had received a legal document of residence at the destination. Of these, more than half had received citizenship, and the remaining 37\% obtained resident permits. The high percentage of migrants acquiring legal documents at the destination is mainly because, the majority have entered their host country legally as refugees, through family reunification, or the DV lottery. This can also be explained by the Beta-Israel's migration, which was largely sponsored by the government of Israel.

\section{Transnational communication and family visits}

The data provided in this comparative analysis suggest legal status plays an important role in shaping different patterns, despite the fact that most people do stay in touch regardless of legal status. Indeed, legal status clearly leads to containment. However, other factors such as income and the characteristics of migrants and their families in Ethiopia also shape the types of communication media employed, which in turn influences the frequency of family contact, and the length, quality and depth of discussion.

Migrant families in Ethiopia tend to use various modes of communication, as long as it is accessible, affordable and simple. Variations in terms of access and ability tend to lead Ethiopian migrants in adopting multiple communication media. Over a third of interviewed households in Gondar communicate with diaspora members at least, once every 2 weeks, and over half communicate at least, once a week. It is important to note that there are significant differences in the access to and use of transnational communication media. Labor migrants who resided in South Africa and their families in rural Ethiopia are less likely to access and use Internet-based communication. As a result, they entirely rely on telephones to maintain family ties. Poor education, lack of access and inability to use the Internet tend to be an explanation.

Ethiopians who resided in Western countries tend to use the telephone to communicate with old and non-educated family members, while email, Facebook, and Skype are used to communicate with younger educated members. However, in Hadiya and Kembata region telephone is the most widely used media and the only means of communication for the majority of households. They are less likely to access and use new media due to low income and illegalisation. Undocumented migrants do not have a data plan, as it requires to acquire proper documentation. More importantly, Internet-based 
communication is not prevalent among households that have members in the Global South, mainly because absent members are low-skilled and their access is limited.

Interestingly, the pattern of international telephone traffic flow in both migration corridors is unidirectional - a phone call occurs from a migrant member to families in Ethiopia, but not likely to be the other way around. Migrant families at either end can initiate communication through the Internet, depending on their skills and access, but also time and space convenience.

In Gondar, transnational families maintain relationships through face-to-face meetings both at home and overseas. The survey found that about three-quarters of respondents were visited by a migrant member in recent years. An overwhelming majority of emigrants had returned to Ethiopia over the last 5 years, with more than half, over the last 2 years. However, such transnational visit is quite rare in Hadiya and Kembata villages as their irregular status creates a situation of 'territorial confinement' (Vickstrom \& Beauchemin, 2016). Income also plays an important role. Even if they are documented, migrants from Hadiya and Kembata villages are less likely to travel back and forth between Ethiopia and South Africa as they did not afford to do so. This is also the case among Ethiopian female domestic migrants in Arab countries. Overall, the differences observed in terms of transnational communication and visits in this comparative analysis are attributed to the legal status differences and income, but this is also a proxy for time/maturity of these migrations or transnational social field.

It is important to note that family visiting is a two-way process. The survey shows $18 \%$ of respondents in Gondar had visited a migrant member abroad; of these, the majority $(80 \%)$ were in the US. Families with multiple diaspora members, who tend to have well-established members overseas, are often more likely to have social capital and are more likely to travel overseas than those who have only a single member. The reverse visit, which is fully sponsored by a diaspora member, demonstrates not only the migrants level of achievement but also boosts their social statuses. Overall, the respondents of the survey are transnational families who maintained strong ties through the use of diverse communication methods such as telephone, email, SMS messaging, and face-to-face visits.

\section{The sending of remittances}

The sending of remittances by migrants is one of the strongest and most pervasive phenomena in Africa's migration system (Adepoju, 1995, p. 100). Corresponding to the increase in cross-border migration, the flow of remittances has surged dramatically. A recent World Bank (2010) study indicated that $14 \%$ of adults in Ethiopia receive remittances regularly. Data obtained from the National Bank of Ethiopia show that official remittances to Ethiopia reached \$US 4 billion in 2017. The actual amount is estimated to be much larger as informal remittances are not captured in official data. Remittances to Ethiopia, which account for some $5 \%$ of the country's GDP, are now exceeded revenues earned from the export sector (Isaacs, 2017). The Middle East and South Africa are two notable places where huge numbers of undocumented migrants are believed to be facing challenges of sending money formally. Out of the 1.2 million migrants in the Middle East and 200,000 in South Africa, 90\% are likely to be remitting informally to Ethiopia (Isaacs, 2017). By the estimates of MoFA, from Saudi Arabia alone, where some 750,000 Ethiopians are believed to be living, 
USD 590 million is estimated to be remitted. A USD 158 million remittance could be sent from migrants in South Africa as well (ibid).

The frequency and intensity of remittance flows were high in Gondar, where migration has been significant for over three decades. All but 12 respondents, (from 544 households) stated that they had received remittances in the past year. Over a third of them have been receiving remittances for more than a decade, while the remaining two-thirds have done so for about a decade, with a quarter in the last 5 years. This shows that Gondar is a mature emigrant community, where migration and remittance recipients have intensified over time. Remittances, on the other hand, are a recent phenomenon in the Hadiya and Kembata villages and they flow from young, male migrants to parents left behind. This is different from the classical labour migration, where remittances typically flow from men to the left behind spouse and children (Stark \& Bloom, 1985). Kanko et al. (2013) reported that $61 \%$ of these migrants send remittances to left behind families on a regular basis, with an average of \$US109. This is low, compared to the average monthly remittance amount in Gondar - \$US252, which was sent on average, seven times a year. This is largely because an overwhelming majority of migrants from Gondar resides in America and investment related flows have grown in recent years. The city of Gondar disproportionately receives remittances from America, while South Africa is the main source of remittances for rural villages in South Ethiopia.

In Gondar, remittances tend to arrive on a monthly basis, for one-third of respondents with most having no alternative sources of income. Others receive them during major public holidays (the Ethiopian New Year in September, Christmas, Epiphany, and Easter) and for investment purposes. Among Muslim households, it would be Eid al-Fitr and Ramadan. In the Hadiya and Kambata regions, the remittance "traffic" is high during Meskel, a holiday celebrated to commemorate the "Finding of The True Cross". In both migration systems, communal values and norms that are based on reciprocity are reinforced through migration. As migrants tend to be financially better-off than those who remain behind, the resource transfer and expectations of support from abroad are growing.

Analysing the dynamics of who sends and who receives remittances is important to understand the motives behind transferring resources, and their impact on recipient families and the community at large. The type of relationship between migrants and those who remain home greatly determine remittance flow patterns. Of 544 interviewed migrant sending-households, the majority $(58.8 \%)$ were male-headed, while the remaining $41.2 \%$ were female-headed, with many widowed. Those who moved to Gondar from the surrounding villages and small towns to pursue college education comprise the largest share of youth-headed households.

The multiple responses indicate that, in Gondar, over three-quarters of household heads receive remittances from their sons and daughters, more than half from siblings, 8.4\% from family-in-law, $4.4 \%$ from parents and another $4.2 \%$ from spouses. The notion of family and kinship in Ethiopia is tied with solid supportive social networks, and this is now widely adopted in the transnational social field. Nearly, three-quarters of migrant households stated that their diaspora members sent remittances to people other than immediate families, with three out of five, sending them to extended family, a little over a quarter, to neighbours and friends, and 3.7\% to family in-laws. These transfers are often based on reciprocity and altruistic motives. In many households, the number of diaspora members exceeds those who live in Ethiopia and in $3.6 \%$ of cases the entire 
family was now living abroad, and extended families stay in these houses. In the latter case, remittances do not decline or stop as Grieco (2004, p. 246) argued:

as the process of family reunification is gradually completed, fewer and fewer immediate kin remain abroad and remittance levels begin to decline. When the last migrant joins the household and all the dependent family members have joined the earliest migrant, the flow of remittances sent back home ends.

This study shows that, instead of declining or ending, remittances are increasingly sent to extended families, friends, neighbours, and local institutions (e.g. churches, mosques). In other words, the horizons of remittance recipients become wider when situations change. This also happens when primary beneficiaries (immediate family members) are not very demanding. Interestingly, migrant households often constitute members beyond the immediate family. More specifically, they help move relatives to the cities from rural areas where access to social services is limited.

Religion tends to play an important role in the reciprocity and sharing of remittance based money with households that do not include migrants and religious institutions. Indeed, religious institutions are the largest recipient of donations from migrants, outside of the immediate family circle. Remittances are increasingly sent to religious institutions, especially during special holidays (e.g. Epiphany) or when they build or renovate buildings or run community projects. The amount of money sent is believed to be large and also includes in-kind items. Community recognition and blessings are of paramount importance in the social and mental wellbeing of the donating family at both origin and destination. Religion, to a certain extent, also play a role in influencing the migration patterns and experiences of migrants. Female domestic labour migration to Arab countries tend to be dominated by Muslims. Migrants use tourist visas and pilgrim or Hajj and Umrah visas to enter Saudi Arabia. Non-Muslim migrants also use pilgrimage as a pretext to enter Saudi Arabia, and then they either move to the third country in the region or try to regularise their visa, otherwise they take the last option, overstaying the visa and working illegally (Zewdu, 2017b).

In the Hadya and Kambata region, villagers, including those who do not send members away, increasingly receive remittances, especially during Meskel and other social events, notably on weddings and funerals. The motive is not only to express happiness or sadness, but also to compensate the non-material support that migrants could have provided if they were not away. In both cases, migrant families increasingly share their resources with other households, not only during crises (illness, accident, death, crop failure, etc.), but also in good times (holidays, weddings, and members' emigration abroad). Resources can be transferred in the form of cash, food, materials or equipment, which otherwise requires large sums of money to buy or rent. This allows persons to save or spend meager resources for other essential purposes. In his study in Ethiopia, Beyene (2012, p. 19) found that a "100 Birr additional remittance leads to a 0.63 percent" increase in the likelihood of transferring resources to other households that do not receive remittances.

Of particular importance, the study observed a substantial exchange of in-kind remittances in Gondar, but not in the South Ethiopia - South Africa migration corridor where migration is dominated by irregular flows. In Gondar, over 
three-quarters of respondents had received electronic equipment, clothes, footwear and medicine in the past year or so and over two-thirds have sent food and cultural clothes/footwear to relatives abroad during the same period. Transnational families opt to send in-kind items whenever they find someone who travels from and to Ethiopia.

\section{Remittance channels}

Another feature related to irregular migration is informal remittance transfer. Isaacs (2017) estimates that, in Ethiopia, as much as $78 \%$ of total remittances may currently be sent through informal channels in some corridors. The South Africa-Ethiopia and the Saudi Arabia-Ethiopia remittance corridors are increasingly characterised by such informal funds transfer systems. In Gondar, remittances are mostly transferred through official channels, but in the Hadiya and Kembata region remittances are sent through informal channels. Since the banking services are neither accessible to undocumented migrants in South Africa, nor to migrant origin villages in Southern Ethiopia, the former tend to establish an informal system as alternative to the formal financial institutions. Although it entails certain risks, the informal money transfers are well organised, efficient and it is as fast as the banking system. Interviews with bank managers showed that there was no direct money transfer from migrants in South Africa to families left behind. However, banks reported that they made large sum payments to people who have presented cheques issued by informal money transfer agents. These informal money transfers are often transnational family businesses, which are run by groups of individuals residing in South Africa and Ethiopia. It is important to note that migrant networks, trust, and confidentiality are the most salient features of informal money transfer in Ethiopia. In Gondar, however, informal remittances are sent through people travelling home for holidays or businesses. Notably, transferring money through formal channels has increased with increasing amounts and frequency of remittances.

\section{Remittance use}

Remittances are the primary, and often the only source of income for more than a third of migrant families in Gondar. They are used for various purposes, depending on the recipient households' socio-economic dynamics. Nearly two-thirds of households spent remittances on food; two out of five on education, and a little over a third on housing and land. Another important area of spending includes clothing, household durables, and social events. In the absence of remittances, a substantial proportion of households would not be able to ensure basic necessities. This is consistent with the study of Aredo (2005), which reported that remittances are increasingly seen as a shock absorber in Ethiopia.

In Hadiya and Kembata villages where migration is recent, remittances are increasingly used to buy food items and repay debts. In both migration systems remittance usage significantly varies with the amount of money received. Spending on consumptive and social expenditure falls with increasing amounts of remittance. The lesser the amount received, the higher the tendency to be used for immediate consumption and social events. Interestingly, in Gondar, spending on education is considerably high, irrespective of the amount of remittances received. However, this is not observed in rural 
villages. Migration has led to a significant decline in school enrolment and increased school dropout rates. In the villages, people's aspiration to go to school and the value attached to education tends to decline with increasing exposure to migration and remittances. On the other hand, in towns, migration tends to have a positive impact on education. Many migrant households send their children to private schools which provide quality education than those of public schools. The negative effects are often due to improper remittance management not the absence of migrant members.

In Gondar, remittances not only insure migrants against poverty but also increasingly enable them to accrue assets and invest in education and businesses, as well as finance the migration of other family members. The purpose of the latter is to diversify risks through multiplying remittance sources or substituting an 'old' remitter with a new one so that the former can slowly retire from having to remit. In Ethiopia, international migration does not only trigger cross-border migration but also intensifies rural-urban migration. Remittances were found to have financed almost a third of respondents in their moves to Gondar from small towns and villages. This is also true in Hadiya and Kembata villages where migrant families increasingly moved to Hosanna, Shashemenie and Addis Ababa, which is more pronounced when migrants return home from South Africa. Those who remain in the villages also enjoy improved social and material well-being. This mobility not only improves their assets and access to quality health, education, and electricity but also exposes them to new technology such as, mobile phones, computers, and the Internet.

Housing, public transport, education, and hotels are the major areas that remittances have brought significant changes in Gondar. Nearly, a third of the first class hotels in Gondar and more than half the public transport vehicles are owned and run by migrant families, returnees or the diaspora. These investments, along with frequent visits from the diaspora, promote tourism. Remittances typically finance public transport activities in Hadiya and Kembata regions. The purchase of transport vehicles measures the success or failure of migration in the region. The Hadiya Zone Transport Bureau estimated that out of 445 buses owned by five transport associations, about $70 \%$ were owned and run by returnees and migrant families. An interview with the Gondar City Transport Bureau indicates that 255 mini-buses and 450 Bajaj's (Indian made three wheeler motorcycles) were providing transport services in the city. Although the bureau lacks accurate data, key-informants estimated that more than half the mini-bus taxis operating in the city are financed through remittances. Gondar has the second largest number of taxis in Ethiopia, next only to Addis Ababa, the capital city. A substantial investment in public transport vehicles does not only alleviate transport problems in the study areas, it also improves the social, economic and trade linkages between areas within and beyond the region, especially the rural-urban sector. Poor infrastructure, low institutional capacity, migrants' low level of education, poor entrepreneurial skills and financial illiteracy inhibits investment. Remittances have a positive multiplier effect through creating a market for local farmers, service providers, and other entrepreneurs. However, it can be argued that the demand side seems more profound than the supply side in stimulating the local economy. The high remittance-induced demand, combined with low productivity and high population growth has contributed to rising living costs which are a challenge for non-migrant families. 


\section{Collective remittances}

One of the most salient features of transnational linkages is the development of migrant organisations, which are often established based on "members" shared experiences and interests, be they professions, ethnic affiliations, or a common hometown' (Somerville, Jamie, \& Terrazas, 2008, p. 1). The role and nature of $\mathrm{HTAs}^{5}$ as development partners for the state and international organisations gained momentum with the surge of remittances (Orozco, 2005). Although they represent a smaller share of family remittances, collective remittances are usually linked to the development of migrants' communities of origin (Goldring, 2004). However, research on collective remittances is relatively small compared to a wealth of literature on individual remittances. Much of the existing literature emphasises HTAs established by Latinos residing in the US.

There has been a debate regarding the use and importance of family and collective remittances. While the former is often regarded as money that acts primarily as a source of income for families and relatives left behind, the latter involves investment and community development, taking into taking into account extra-economic dimensions of remittances, particularly the social and political meanings and uses of remittances (Goldring, 2004).

The amount of collective remittances to Ethiopia is low, partly because the participation of diaspora members in HTAs is quite small. However, both documented and undocumented immigrants send donations to community projects through their families. Many do this as they have more trust in family networks over government and NGO structures. The collective funding provided by migrants help to channel resources to origin communities. The first generation emigrants from the Gondar region have established a hometown association in the US named Gondar Development and Cooperation Organisation (GDCO). It was established in 1992 - the period (i.e. the late 1980s and early 1990s) when HTAs became popular across the world (Orozco, 2005). This HTA has made a considerable contribution to building human capital resources and expanding education and health infrastructure in Gondar. However, HTAs tend to benefit urban more than rural areas, and mature more than emerging migrant communities. Political distrust and poor partnerships increasingly limit the potential of migrant organisations.

Despite intensifying level of migration and huge fund transfers, local government structures have provided little attention to the issue of migration, and could not able to mobilise the otherwise huge potential. Notably, in 2009 the Hadiya Development Association (HDA) managed to raise an estimated Birr 2.6 million (over US\$200,000) in a fundraising campaign launched in South Africa. However, they couldn't harness the diaspora resources in an organised and sustainable fashion. The local government, neither puts a strategy in place to create networking with the diaspora nor provide them with sufficient technical support. On the other hand, the Gondar Development and Cooperation Organisation (GDCO) has been providing economic support for disadvantaged students (a total of 2311 students between 1996 and 2012) and building the capacity of schools and hospitals in Gondar. Besides sending funds, the HTA has been providing medical equipment, books, computers, training for local medical staff, and voluntary professional services for patients.

Rural areas in south Ethiopia send low-skilled migrants, predominantly to South Africa, through irregular channels and hardly benefit from migrant organisations. They 
tend to be emerging migrant communities; where the outflow has been recent, and HTAs tend to develop as migration outflow mature, as Somerville et al. (2008) noted. Of particular note, local institutions such as Iqub (traditional saving association) which is commonly practiced in Ethiopia are now adopted by migrants residing in South Africa. Those who engage in Iqub, for example, send collective remittances back home during weddings, funerals, and public holidays. These informal institutions have a high potential for growth and to engage in collective remittances if they receive the required support including acquiring permanent residence or authorization in South Africa. However, there is no way that these migrants are able to obtain legal documents in South Africa. As Goldring (2004) suggests, HTAs are not born overnight; they need time to achieve success, build a base of effective leadership and accumulate political learning. Indeed, in the case of Gondar, the migration system has evolved from being a mainly refugee migration system (with that legal status in the US) to one where sponsorship and permanent residence (green cards) predominate. This suggests the importance of time and temporalities in discussing a migrant's life course and his/her transnational engagement.

\section{Negative effects}

Remittances have also negative impacts. The rising costs of living are one of the most notable adverse effects of remittances to migrant-sending areas. Life is expensive in Hosanna compared to other big cities within $100 \mathrm{~km}$ distance (i.e. Hawassa - the regions capital and Jimma, a city with an estimated population of 350,000 fourfold than Hosanna town). Similarly, living expenses are much higher in Gondar than any other big city in the region and it is comparable with that of Addis Ababa. Focus group participants in the study areas reported that migrant families, neither bargain nor resist unfair prices while buying goods and services. This is due to the fact that they have high purchasing power than other residents. In Hosanna, those families who receive remittances from South Africa are named "ene yihunie metu" (literally means those people who agree to purchase goods for any price). This is also explained by the easily spendable nature of remittances (Ghosh, 2006). In Gondar, youth remittance recipients who are neither studying nor engaged in paid or unpaid family work are usually named "wetat turetegna" literally means "youth pensioners". The negative effects are mainly caused by poor remittance management along with the absence of government support at the grassroots level.

Migration has led to a significant decline in school enrolment and increase school dropout rates in Hadiya and Kembata region. On the other hand, in Gondar, migration tends to have a positive impact on education. Many migrant households send their children to private schools which provide quality education than those of public schools. Remittances also enable many students to own or access relevant educational resources and enable them to acquire particular skills (e.g. computer, English language).

The level of appreciation given for migrant remittances varies depending on the migrants' place of residence, level of perceived and actual risks that they incur during or after migration. Families that receive remittances from relatives 
residing in South Africa and Arab countries tend to be more grateful, compared to others who receive them from Western countries. This is not because of the amount of money sent, but because of the socially constructed meaning of remittances. Remittances from Arab and African countries are perceived as money earned amid risks and through hard work. Remittances from Western countries, on the other hand, are assumed to be a tiny portion of income sent by rich diaspora member.

\section{Conclusion}

This article attempts two kinds of analytical work. First, its comparative perspective helps to understand the different migration systems that have arisen within one country, and explaining them in a way that takes into account several dimensions and variables. As is the case in major migrant origin countries (Hugo, 2012) migrant workers have usually drawn from specific areas or regions in Ethiopia, partly indicating the function of social networks. In both migration systems, where a "culture of migration" develops, there is a high aspiration to emigrate. Indeed this appears to be true for the entire country. Migrant networks are important in increasing aspirations and capabilities of residents to migrate, and their decisions about where and how to emigrate. The migration experience at the community level also influences people's decision to migrate and shapes the pattern of migratory flows. The cases studied confirm that migration is a "strongly socially structured and spatially patterned process" (De Haas, 2011, p. 15).

In this study, more differences than similarities are observed between the two migration systems in terms of the causes, processes, and composition of migration flows, as well as the ways in which migrants and their families engage transnationally. The data suggest that migration began in different ways in Gondar and Hadiya and Kembata regions, indicating that a single theory of migration is unlikely to account for migration from a given country, given that most exhibit some level of distinct regional histories. Much of the differences that are currently evident is associated not only with the "maturity" or temporal depth of migration from these regions, but also with the legal status of migrants during travel, and upon reaching the destination. While migration from the Gondar region has evolved from being a mainly refugee migration system (with that legal status in the US) to one where sponsorship and permanent residence (green cards) predominate. However, there was no way for unskilled, rural migrants from the southern regions of Ethiopia to acquire permanent residence or authorisation in South Africa. In other words, the majority of these migrant workers remain undocumented for a significant period of time. The legal status and associated mobility and immobility factors are increasingly affecting the migration outcome of these migrants. It is likely that the occupations and earnings of US-based diasporas are different compared to those departing to South Africa and Arab countries.

While the composition and drivers of migration from the Gondar region have changed significantly over time, it remains much the same in rural areas where the youth (mainly males) emigrate for economic reasons. The causes that initiate international movement and sustain it over time differ considerably, especially in areas where migration was initiated by non-economic reasons. This claim, however, does not appear to work for areas associated with labor migration where economic reasons remain key drivers. This paper shows that social class, resources, gender and poverty are key 
variables along which migration from Ethiopia is being stratified, and there is also important sub-national variation. This has grown more visible since the late-1990s with an influx of both skilled and unskilled migrants from Ethiopia migrating to different destinations. Not all Ethiopian migrants have the same experiences, and this has a lot to do with the regional organisation of migration. Different histories locally, and transnationally, generate different outcomes.

Second, this study attempts to understand how emigration patterns affect the ways in which emigrants operate within transnational spaces, including return visits, non-direct family contacts, amount, frequency, channel and types of remittances sent. The frequency and intensity of remittances were found to be high in both regions. However, the channels vary accordingly. The remittance literature often relates informal remittance flows to the cost of remittances, and not so much with the patterns of migration. Regions that send undocumented migrants often receive remittances (mainly cash) through informal channels, while areas where outflow is dominated by documented migrants receive remittances (both cash and in-kind) through official channels. In the latter case, the reverse remittances are also substantial. However, in-kind and reverse remittances are absent among undocumented migrants, as they are unable to travel back and forth across borders. This is mainly because unofficial (re)entry involves higher physical, financial, and legal risks (Koser, 2010; Vickstrom \& Beauchemin, 2016).

Remittances are often used for various purposes in mature urban emigrant communities, compared to emerging rural sending areas. In Gondar, although high expenditure on daily consumption and social events has been steady for over two decades, in recent years there has been a change in spending on asset building, investment, and on other productive activities. Deprived villagers often use remittances to meet basic family needs, to buy household equipment and to repay debts. The better-off families, on the other hand, use remittances to buy plots of lands and houses in cities, buy consumer durables and invest in the public transport sector.

International migration and remittances tend to encourage rural-urban migration and increase children's access to quality education in the new destinations, however in the villages, people's aspiration to go to school and the value attached to education tends to decline with increasing exposure to migration and remittances. The departure of migrants and the money they send home can affect the social standing of recipient families, as other studies in Africa have shown (e.g., Åkesson, 2011; Bracking, 2003). These, however, vary depending on geographical location and the length of time that the community has been exposed to migration and its benefits. In Gondar, households with members in Western countries and those with multiple members abroad enjoy more respect and improved social statuses compared to non-migrant families and those with members in non-Western destinations.

The findings confirm that the impact of migration on the community is increasingly manifested through the transnational engagements of migrants. This benefit, however, is more pronounced among mature urban migrant-sending communities than emerging rural sending areas. The transnational activities of low skilled, undocumented labour emigrants are often limited to sending remittances home. The interplay of different factors, such as the characteristics of emigrants, notably, their education, income and legal status at the destination, can determine the extent to which they engage in home community development. This study suggests that skilled migrants are more likely than 
others to participate in collective remittances and give back to origin communities. However, limited participation in HTAs does not imply low community engagement among undocumented labour migrants as they intermittently send donations to community projects through their families. The data provided in this comparative analysis suggests the importance of taking into account the cultural, social, ethnic, geographic, economic differences that exist in a country of origin, not just the legal status of immigrants and their level of integration at destinations. Moreover, legal status does not just affect immigrants integration and their transnational engagement (Baldwin-Edwards, 2008; Vickstrom \& Beauchemin, 2016) but also the transnational activities of those who remained at home.

\section{Endnotes}

${ }^{1}$ Its capital is called Duramie (town)

${ }^{2}$ Its capital is called Hosanna (town)

${ }^{3}$ Six female-headed and five male-headed households; and two female and two male youth household members were interviewed

${ }^{4}$ The Diversity Visa program, also known as the green card lottery, is a United States government lottery program for receiving a Permanent Resident Card. It makes available 50,000 Diversity Visas each year.

${ }^{5}$ Also referred to as collective remittances

\section{Acknowledgements}

This work is dedicated to the memory of my late sister Selamawit Adugna, gone far too soon and my father, Adugna Zewdu, who always believed in my ability to be successful in the academic arena. You are gone but your belief in me has made this journey possible. I am grateful to my late supervisor Prof. Graeme Hugo for his mentorship, invaluable advice and encouragement throughout my PhD study. I would also like to thank the two anonymous reviewers for their constructive comments and suggestions, and Mesfin Awoke, Getaneh Agegn and Augustine Sesay for their invaluable help proofreading the manuscript.

Funding

The author wishes to thank the University of Adelaide for its support to conduct this research.

Availability of data and materials

The data that support the findings of this study are available from the author upon request. Indeed, the dataset supporting the conclusions of this article is included within the article.

\section{Author's contributions}

GA is the sole author. He collected and analysed data thanks to the support of the University of Adelaide. The author read and approved the final manuscript.

\section{Author's information}

Girmachew Adugna is a former Research Fellow at the Hugo Centre for Migration and Population Research Centre, University of Adelaide. He completed his PhD at the University of Adelaide, Australia and has conducted research in Ethiopia, Australia and Norway. His research interests are in the areas of international migration, transnational families, remittances, and diaspora engagement. Email: girmadugna@yahoo.com

Competing interests

The author declares that he has no competing interests.

\section{Publisher's Note}

Springer Nature remains neutral with regard to jurisdictional claims in published maps and institutional affiliations.

Received: 24 July 2017 Accepted: 14 December 2018

Published online: 18 February 2019

\section{References}

Adepoju, A. (1995). Migration in Africa. In J. Baker, \& T. A. Aina (Eds.), The migration experience in Africa, (pp. 87-108). Uppsala: Nordiska Afrikaninstitutet.

Åkesson, L. (2011). Remittances and relationships: exchange in Cape Verdean transnational families. Ethnos, 76(3), 326-347. 
Aredo, D. (2005). Migrant remittances, shocks and poverty in urban Ethiopia: an analysis of micro-level panel data. Addis Ababa: Addis Ababa University.

Ariza, M. (2014). A comparative approach to global domestic service in two cities: methodological notes. In L. Rivera-Sánchez, \& F. Lozano-Ascencio (Eds.), The practice of research on migration and mobilities, (Vol. 14). SpringerBriefs in Environment, Security, Development and Peace. https://doi.org/10.1007/978-3-319-02693-0.

Baldassar, L. (2008). Missing kin and longing to be together: emotions and the construction of co-presence in transnational relationships. Journal of Intercultural Studies, 29(3), 247-266.

Baldwin-Edwards, M. (2008). Towards a theory of illegal migration: historical and structural components. Third World Quarterly, 29(7), 1449-1459.

Beyene, B. M. (2012). The link between international remittances and private inter-household transfers (No. 14/2012). Memorandum, Department of Economics, University of Oslo. Retrieved from https://pdfs.semanticscholar.org/4bad/ 1483c95375a7fd4dbec4629dea9fec565217.pdf

Bracking, S. (2003). Sending money home: are remittances always beneficial to those who stay behind? Journal of International Development, 15(5), 633-644.

Bryceson, D., \& Vuorela, U. (2002). Transnational families in the twenty-first century. In D. Bryceson, \& U. Vuorela (Eds.), The transnational family: new European frontiers and global networks. Oxford: Berg.

Button, K. L., \& Vega, H. (2008). The effects of air transportation on the movement of labor. GeoJournal, 71(1), 67-81.

Castañeda, E., Morales, M. C., \& Ochoa, O. (2014). Transnational behavior in comparative perspective. Comparative Migration Studies, 2(3), 305-333.

Castles, S. (2007). Twenty-first-century migration as a challenge to sociology. Journal of Ethnic and Migration Studies, 33(3), $351-371$.

Castles, S., De Haas, H., \& Miller, M. J. (2014). The age of migration. International population movements in the modern world. New York: Palgrave MacMillan Higher Education.

Coutin, S. B. (2000). Legalizing moves: Salvadoran immigrants'struggle for U.S. residency. MI: University of Michigan Press.

Cvajner, M., \& Sciortino, G. (2010). Theorizing irregular migration: the control of spatial mobility in differentiated societies. European Journal of Social Theory, 13(3), 389-404.

De Genova, N. P. (2002). Migrant "illegality" and deportability in everyday life. Annual Review of Anthropology, 31, 419-447.

De Haas, H. (2011). The determinants of international migration: Conceptualising policy, origin and destination effects (DEMIG Working Paper No. 32-11). Oxford: Oxford University, International Migration Institute. Retrieved from https://www.imi.ox.ac.uk/publications/wp-32-11.

Donato, K. M., \& Armenta, A. (2011). What we know about unauthorized migration. Annual Review of Sociology, 37, 529-543.

Düvell, F., \& Jordan, B. (2002). Irregular migration: the dilemmas of transnational mobility. Cheltenham: Edward Elgar.

Evans, A. (1991). Gender issues in rural household economics. IDS Bulletin, 22(1), 51-59.

Faist, T. (2010). Academic knowledge, policy and the public role of social scientists. The case of migration and development. (COMCAD,Working Paper No. 71). Bielefeld.

Federal Democratic Republic of Ethiopia Population Census Commission. (2008). Summary and Statistical Report of the 2007 Population and Housing Census. Population Size by Age and Sex. Retrieved from Ethiopian Review. http://www.ethiopianreview.com/pdf/001/Cen2007_firstdraft(1).pdf.

Getahun, S. A. (2007). The history of Ethiopian immigrants and refugees in America, 1900-2000: patterns of migration, survival, and adjustment. New York: LFB Scholarly Pub. LLC. Retrieved from https://www.ifbscholarly.com.

Ghosh, B. (2006). Migrants' Remittances and Development: Myths, Rhetoric and Realities. Geneva: International Organisation for Migration. Retrieved from http://publications.iom.int/system/files/pdf/migrants_remittances.pdf.

Glick Schiller, N., Basch, L. G., \& Blanc, S. C. (Eds.) (1992). Toward a transnational perspective on migration. New York: New York Academy of Sciences.

Goldring, L. (2004). Family and collective remittances to Mexico: a multi-dimensional typology. Development and Change, 35(4), 799-840.

Goldring, L. \& Landolt, P. (2012). The Impact of Precarious Legal Status on Immigrants' Economic Outcomes (IRPP study No. 35). Montreal: Institute for Research on Public Policy. Retrieved from http://irpp.org/researchstudies/the-impact-of-precariouslegal-status-on-immigrants-economic-outcomes/.

Goldring, L., \& Landolt, P. (2014). Transnational migration and the reformulation of analytical categories: unpacking Latin American Refugee dynamics in Toronto. In L. Rivera-Sánchez, \& F. Lozano-Ascencio (Eds.), The Practice of research on migration and mobilities, (vol. 14). SpringerBriefs in Environment, Security, Development and Peace. https://doi.org/10.1007/978-3-319-02693-0_1.

Grieco, E. (2004). Will migrant remittances continue through time? A new answer to an old question. International Journal on Multicultural Societies, 6(2), 243-252

Guyer, J. I. (1981). Household and community in African studies. African Studies Review, 24(2/3), 87-137. https://doi.org/10. $2307 / 523903$.

Haug, S. (2008). Migration networks and migration decision-making. Journal of Ethnic and Migration Studies, 34(4), $585-605$.

Horwood, C. (2009). In pursuit of the southern dream: victims of necessity, Assessment of the irregular movement of men from East Africa and the Horn to South Africa. Retrieved from publications.iom.int/bookstore/free/IOMResearchAssessment.pdf

Hosnedlová, R., \& Stanek, M. (2014). Analysing selected transnational activities among Ukrainian immigrants in Spain. Central and Eastern European Migration Review, 3(1), 99-114.

Hugo, G. (2012). Migration and development in low-income countries: A role for destination country policy? Migration and Development, 1(1), 24-49.

Isaacs, L. (2017). Scaling up formal remittances to Ethiopia: the executive summary of a research study to enhance the volume and value of formal remittances to Ethiopia. Retrieved from http://www.developingmarkets.com/sites/default/files/ Ethiopia\%20Executive\%20Summary\%2018.pdf.

Itzigsohn, J., \& Giorguli-Saucedo, S. (2002). Immigrant incorporation and sociocultural transformation. International Migration Review, 36(3), 766-798.

Kanko, T. D., Bailey, A., \& Teller, C. (2013, August). Irregular Migration: Causes and Consequences of Young Adult Migration from Southern Ethiopia to South Africa. Paper presented at XXVII IUSSP International Population Conference, Busan, South Korea (pp. 26-31). Paper retrieved from https://iussp.org/sites/default/files/event_call_for_papers/ Irregular\%20Migration\%20from\%20south\%20Ethiopia\%20to\%20South

Koser, K. (2010). Dimensions and dynamics of irregular migration. Population, Space and Place, 16(3), 181-193. 
Lacroix, T., Levitt, P., \& Vari-Lavoisier, I. (2016). Social remittances and the changing transnational political landscape. Comparative Migration Studies, 4. https://doi.org/10.1186/s40878-016-0032-0

Levitt, P. (1998). Social remittances: migration driven local-level forms of cultural diffusion. International Migration Review, $32(4), 926-948$

Lucas, R. E. (2008). International labor migration in a globalizing economy. Carnegie Endowment for International Peace. Paper n. 92 Lundvall B-A No.92. http://www.carnegieendowment.org. Accessed 3 April 2017.

Lyons, T. (2009). 'Ethiopian Diaspora and homeland conflict'. In S. Ege, H. Aspen, B. Teferra, \& S. Bekele (Eds.), Proceedings of the 16th International Conference of Ethiopian Studies, 2. Trondheim: Norwegian University of Science and Technology. Retrieved from https://ilpi.org/wp-content/uploads/2014/09/Nolume-2-Complete-version.pdf

Malini, F. (2014). Transnationalism and integration: what kind of relationship? Empirical evidence from the analysis of codevelopment's dynamics. Migration and Development, 3(2), 306-320. https://doi.org/10.1080/21632324.2014.919715.

Massey, D. S., Alarcon, R., Durand, J., \& Gonzdilez, H. (1987). Return to Aztlan: the social process of international migration from Western Mexico. Berkeley: University of California Press.

Massey, D. S., Arango, J., Hugo, G., Kouaouci, A., Pellegrino, A., \& Taylor, J. E. (1999). Worlds in motion: Understanding international migration at the end of the millennium. Oxford: Clarendon Press.

Menjívar, C. (2011). The Power of the Law: Central Americans' Legality and Everyday Life in Phoenix, Arizona. Latino Studies, 9(4), 377-395.

Morales, L., \& Jorba, L. (2010). The transnational practices of immigrants' associations in Spain. In R. Bauböck, \& T. Faist (Eds.), Diaspora and transnationalism: concepts, theories and methods. Amsterdam: Amsterdam University Press.

Orozco, M. (2005). Transnationalism and development: trends and opportunities in South America. In S. M. Miambo, \& D. Rather (Eds.), Remittances: development impact and future prospects. Washington DC: World Bank.

Piper, N. (2018). Gendering the Politics of Migration. International Migration Review, 40(1), 133-164 https://doi.org/10.1111/j.1747-7379.2006.00006.x.

Portes, A. (2003). Conclusion: theoretical convergencies and empirical evidence in the study of immigrant transnationalism. International Migration Review, 37(3), 874-892.

Ramji-Nogales, J. (2015). "The right to have rights": undocumented migrants and state protection. Kansas Law Review, 63, 1045-1065 Retrieved from https://kuscholanworks.ku.edu/bitstream/handle/1808/20300/9-Ramji-Nogales_Updated_Page_Numbers.pdf? sequence=1.

Rivera-Sánchez, L., \& Lozano-Ascencio, F. (2014). The practice of research on migration and mobilities, (Vol. 14). SpringerBriefs in Environment, Security, Development and Peace. https://doi.org/10.1007/978-3-319-02693-0.

Schluter, C., \& Wahba, J. (2009). Illegal Migration, Wages, and Remittances: Semi-Parametric Estimation of Illegality Effects (Discussion Paper No. 4527). Retrieved from http://ftp.iza.org/dp4527.pdf

Somerville, W. Durana J., \& Terrazas, A.M. (2008). Hometown associations: an untapped resource for immigrant integration. Retrieved from Migration Policy Institute https://www.migrationpolicy.org/research/hometown-associations-untappedresource-immigrant-integration.

Stark, O., \& Bloom, D. E. (1985). The new economics of labor migration. The American Economic Review, 75(2), 173-178.

Terrazas, A. (2007). Beyond regional circularity: The emergence of an Ethiopian diaspora. Migration Information Source. Retrieved from Migration Policy Instute https://www.migrationpolicy.org/article/beyond-regional-circularity-emergenceethiopian-diaspora.

Torres, A., \& Gioconda Herrera, G. (2014). Investigating at the "source": rethinking the transnational social space from the contexts of departure. In L. Rivera-Sánchez, \& F. Lozano-Ascencio (Eds.), The practice of research on migration and mobilities, (Vol. 14). SpringerBriefs in Environment, Security, Development and Peace. https:/doi.org/10.1007/978-3-319-02693-0.

Vertovec, S. (2004). Cheap calls: the social glue of migrant transnationalism. Global Networks, 4(2), 219-224.

Vezzoli, S. (2014). Unpacking the 'colonial dummy': An exploration of the role of decolonization and state formation in migration processes (IMI/DEMIG Working Paper, No. 102). Oxford: University of Oxford: International Migration Institute.

Vickstrom, E. R., \& Beauchemin, C. (2016). Irregular status, territorial confinement, and blocked transnationalism: legal constraints on circulation and remittances of Senegalese migrants in France, Italy, and Spain. Comparative Migration Studies, 4. https://doi.org/10.1186/s40878-016-0037-8.

Waters, M. C., \& Gerstein Pineau, M. (Eds.) (2016). The integration of immigrants into American society. Washington, DC: National Academies Press.

World Bank (2010). Survey research examining remittance flows into Ethiopia, Executive summary of findings. Addis Ababa. Retrieved 12 February, 2015 from https://datacatalog.worldbank.org/dataset/ethiopia-futureafrican-remittances-national-surveys-2010

Zewdu, G. A. (2017a). Ethiopian female domestic labour migration to the Middle East: patterns, trends, and drivers. African and Black Diaspora: An International Journal, 11(1). https://doi.org/10.1080/17528631.2017.1342976.

Zewdu, G. A. (2017b). The dynamics of transnational family relations and remittance flow in Ethiopia. Population, Population Space and Place, 24(5). , https://doi.org/10.1002/psp.2126. 